\section{Studying Ocean Acidification in the Arctic Ocean}

The U.S. Geological Survey (USGS) partnership with the U.S. Coast Guard Ice Breaker Healy and its United Nations Convention Law of the Sea (UNCLOS) cruises has produced new synoptic data from samples collected in the Arctic Ocean and insights into the patterns and extent of ocean acidification. This framework of foundational geochemical information will help inform our understanding of potential risks to Arctic resources due to ocean acidification.

\section{Global Context}

The oceans of the world naturally act as a reservoir for carbon dioxide $\left(\mathrm{CO}_{2}\right)$ and have absorbed about one-third of the total anthropogenic $\mathrm{CO}_{2}$ emissions during the past 200 years (Sabine and others, 2004). Although this net oceanic uptake of $\mathrm{CO}_{2}$ may have moderated the rate of anthropogenic climate change, this uptake has caused rapid and unprecedented changes to ocean chemistry, reducing $\mathrm{pH}$ of surface waters and leading to a series of chemical changes collectively known as ocean acidification. Ocean chemistry and the changes caused by increasing atmospheric $\mathrm{CO}_{2}$ are well understood and can be precisely calculated, however, the direct biological effects of ocean acidification are less certain. Responses will likely vary among organisms, with some adapting well and others not at all. However, ocean acidification may affect the ability of organisms to produce and maintain shell material such as aragonite or calcite (calcium carbonate minerals structured from carbonate ions) required by many shelled organisms, from mollusks to corals to other microscopic organisms at the base of the food chain. Within the next 100 years, significant changes are likely in marine ecosystems and their services, based on the longterm effects of ocean acidification (Raven and others, 2005). Thus, understanding present global marine ecosystems - their geochemistries and susceptibilities to acidification processeswill help provide realistic chemical parameters and metrics to assess more precisely the potential future scale and scope of effects of ocean acidification.

\section{Acidification of the Arctic Ocean}

The cold surface waters of the Arctic Ocean absorb atmospheric $\mathrm{CO}_{2}$ more rapidly than warmer waters, leading to a disproportionately higher fraction of the global net $\mathrm{CO}_{2}$ uptake. Climatic changes have intensified this susceptibility to ocean acidification (Mathis, 2011). Up until recently the perennial ice cover has prohibited significant equilibration with the atmosphere, creating a polar mixed layer that was undersaturated with respect to atmospheric $\mathrm{CO}_{2}$. However, over the last three decades melting of more summer sea ice cover has
The USGS has collected new high-resolution geochemical data for extensive areas of the Arctic Ocean in collaboration with the University of South Florida and U.S. Coast Guard to assess the potential for and current extent of ocean acidification. Ocean acidification in the Arctic will affect marine geochemical and biological processes and may cause reduced shell formation, habitat loss, and possibly less food for predators.

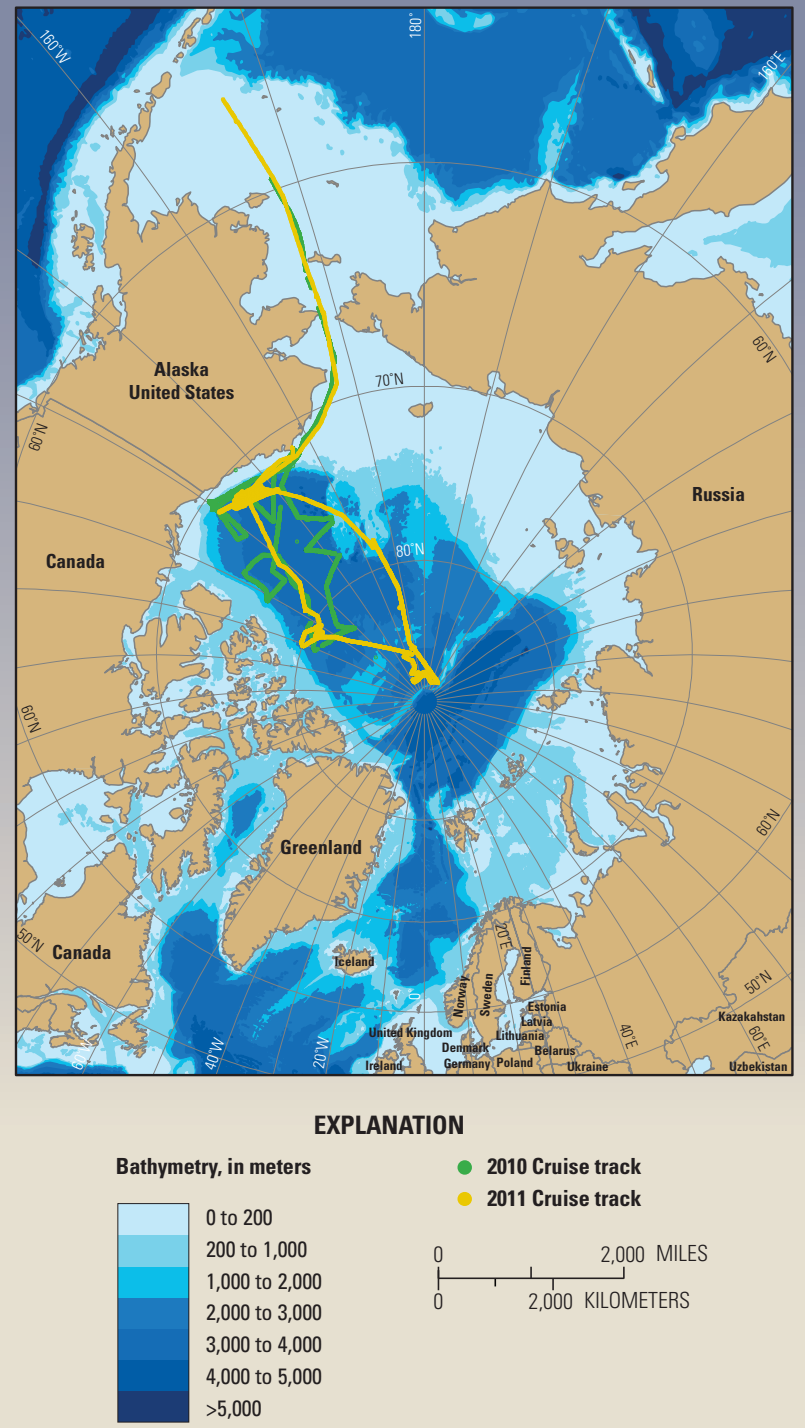

Cruise tracks from the 2010 and 2011 seasons plotted over shaded bathymetry. 
added freshwater to the ocean, has increasingly exposed shelf waters, and allowed greater $\mathrm{CO}_{2}$ exchange to occur in these cold waters. The combination of these processes accelerates the rates at which both $\mathrm{pH}$ and the carbonate mineral saturation state decrease.

Although model simulation results project that the Arctic Ocean will become undersaturated with respect to carbonate minerals in the next decade, some recent field results indicate that regions of this ocean already may have reached this state. The studies have shown the decreased saturation state of carbonate mineral aragonite when ice melt is at its largest extent during late summer. These regions have include localized areas on the Canadian Archipelago and Beaufort Sea shelves (Bates and others, 2009; Chierici and Fransson, 2009; YamamotoKawai and others, 2009). The uncertainty of current models to simulate future trends of ocean acidification, particularly in the higher Arctic latitudes, is due to a lack of spatial and temporal resolution.

\section{USGS Sampling 2010-11}

The USGS initiated a new effort that builds on the fundamental baseline data currently available for coastal Bering Sea Shelf and the Arctic Ocean (Azetsu-Scott and others, 2010; Mathis, 2011; databases available at Carbon Dioxide Information Analysis Center (CDIAC), Japanese Agency for Marine Earth Science and Technology (JAMSTAC), and Canadian Department of Fisheries). In 2010 and 2011, we collected water chemistry during 5- and 7-week UNCLOS cruises. Data from the 2010 and 2011 cruises complement the previously available coastal data, but provide unique datasets helpful in testing numerous hypotheses associated with ocean acidification from coastal to open ocean at high latitudes. Flowthrough and discrete water samples were collected on these two cruises.

- Underway flow-through sampling: Samples were collected from a continuous flow water system and analyzed using a state of the art Multiparameter Inorganic Carbon Analyzer every 7 minutes for $\mathrm{pH}$, partial pressure of carbon dioxide in the water $\left(\mathrm{pCO}_{2}\right)$, and dissolved inorganic carbon. An unprecedented 34,000 measurements were made in the Canadian Basin during 2010 and 2011.

- Discrete samples of surface water also were collected every hour and immediately analyzed for $\mathrm{pH}$ and carbonate ion concentration.

- Additional discrete samples of surface water were collected approximately every $1-4$ hours for total alkalinity/total carbon, nutrients $\left(\mathrm{NH}_{4}-\mathrm{N}\right.$, Silica, $\mathrm{PO}_{4}$, and $\left.\mathrm{NO}_{3}-\mathrm{N}\right)$, stable carbon and oxygen isotopic composition, elemental analysis, dissolved organic carbon, and particulate organic carbon, for later laboratory analysis.

These data form one of the highest resolution and comprehensive datasets on carbonate chemistry in Arctic waters. The data are then used to calculate saturation state of the water, which is a reflection of whether carbonate minerals (that is, shells) will dissolve and provide information on habitat responses to ocean acidification.
The USGS efforts in 2010 and 2011 illustrate the availability and value of high resolution, systematic carbon chemistry sampling of the Arctic Ocean from coastal to high-latitude pelagic waters can help decision-makers and scientists assess the effects of ocean acidification on flora and fauna of the Arctic Ocean.

This research was funded by the U.S. Geological Survey Coastal and Marine Program and the U.S. Geological Survey Office of the Regional Executive-Alaska and in partnership with the University of South Florida and U.S. Coast Guard.

\section{References Cited}

Azetsu-Scott, K., Clarke, A., Falkner, K., and others, 2010, Calcium carbonate saturation states in the waters of the Canadian Arctic Archipelago and the Labrador Sea: Journal of Geophysical Research-Oceans, v. 115, no. C11021, 18 p., doi:10.1029/2009JC005917.

Bates, N.R., Mathis, J.T., and Cooper, L.W., 2009, Ocean acidification and biologically induced seasonality of carbonate mineral saturation states in the western Arctic Ocean: Journal of Geophysical Research, v. 114, no. C11007, 21 p.

Chierici, M., and Fransson, A., 2009, Calcium carbonate saturation in the surface water of the Arctic OceanUndersaturation in freshwater influenced shelves: Biogeosciences, v. 6, no. 11, p. 2421-2432.

Mathis, J.T., 2011, The extent and controls on ocean acidification in the western Arctic Ocean and adjacent continental shelf seas in Arctic Report Card, 2011 National Oceanic and Atmospheric Administration, accessed March 12, 2012, at http://www.arctic.noaa.gov/reportcard/ocean_acidification. html.

Raven, J., Caldeira, K., Elderfield, H., and others, 2005, Ocean acidification due to increasing atmospheric carbon dioxide: Royal Society Policy Document 12/05, 68 p.

Sabine, C.L., Feely, R.A., Gruber, N., and others, 2004, The oceanic sink for anthropogenic $\mathrm{CO}_{2}$ : Science, v. 305 , no. 5682 , p. 367-371.

Yamamoto-Kawai, M., McLaughlin, F.A., Carmack, E.C., Nishino, S., and Shimada, K., 2009, Aragonite undersaturation in the Arctic Ocean-Effects of ocean acidification and sea ice melt: Science, v. 326, no. 5956, p. 1098-1100.

\section{Author: Lisa Robbins}

\section{For Information Contact:}

Regional Executive for Alaska

U.S. Geological Survey

4210 University Dr.

Anchorage, AK 99508

http://alaska.usgs.gov

907-786-7000 